RIS E OF THE RED ENGINEER 
EAST-WEST CENTER

S e r I e s on Contemporary Issues in Asia and the Pacific

S ERIES C O-E D I T OR S

fohn T. Sidel, London School of Economics

Geoffrey M. White, East-West Center and University Of Hawai' $i$

E D I T ORIAL B OAR D

Kellee S. Tsai, Fohns Hopkins University Sheila A. Smith, Council on Foreign Relations

Peter Xenos, East-West Center 
A Series Sponsored by the East-West Center

\title{
CONTEMPORARY ISSUES IN ASIA AND THE PACIFIC
}

\author{
John T. Sidel and Geoffrey M. White, Series Co-Editors
}

\begin{abstract}
A collaborative effort by Stanford University Press and the East-West Center, this series focuses on issues of contemporary significance in the Asia Pacific region, most notably political, social, cultural, and economic change. The series seeks books that focus on topics of regional importance, on problems that cross disciplinary boundaries, and that have the capacity to reach academic and other interested audiences.

The East-West Center is an education and research organization established by the U.S. Congress in 1960 to strengthen relations and understanding among the peoples and nations of Asia, the Pacific, and the United States. The Center contributes to a peaceful, prosperous, and just Asia Pacific community by serving as a vigorous hub for cooperative research, education, and dialogue on critical issues of common concern to the Asia Pacific region and the United States. Funding for the Center comes from the U.S. government, with additional support provided by private agencies, individuals, foundations, corporations, and the governments of the region.
\end{abstract}



J O E L A N D R A S

\section{Rise of the Red Engineers}

The Cultural Revolution and the Origins of China's New Class 
Stanford University Press

Stanford, California

(C) 2009 by the Board of Trustees of the Leland Stanford Junior University. All rights reserved.

No part of this book may be reproduced or transmitted in any form or by any means, electronic or mechanical, including photocopying and recording, or in any information storage or retrieval system without the prior written permission of Stanford University Press.

Printed in the United States of America on acid-free, archival-quality paper Library of Congress Cataloging-in-Publication Data

Andreas, Joel.

Rise of the red engineers : the Cultural Revolution and the origins of China's new class / Joel Andreas.

p. cm. -- (Contemporary issues in Asia and the Pacific)

Includes bibliographical references and index.

ISBN 978-0-8047-6077-5 (cloth : alk. paper) -- ISBN 978-0-8047-6078-2 (pbk. : alk. paper)

I. Elite (Social sciences)--China--History--2oth century. 2. Social classes-China--History--2oth century. 3. Power (Social sciences)--China--History-2oth century. 4. Engineers--China--History--2oth century. 5. China-History--Cultural Revolution, I966-1976. I. Title. II. Series: Contemporary issues in Asia and the Pacific.

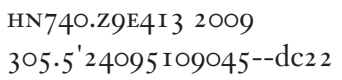

Typeset at Stanford University Press in 9.75/1 3.5 Janson Text 
For my mother, Carol Andreas (1933-2004), who made me care about social injustice and set me on the path of exploring its causes. 
